PRZEGLĄD RUSYCYSTYCZNY 2020, nr 4(172)

DOI $10.31261 /$ pr.

IWONA KRYCKA-MICHNOWSKA

Uniwersytet Warszawski

(D) ORCID: https://orcid.org/oooo-0oo1-7293-1240

\title{
Z DZIEJÓW ROSYJSKIEJ EMIGRACJI W POLSCE MIĘDZYWOJENNEJ: EUGENIA WEBER-CHIRIAKOWA
}

FROM THE HISTORY OF RUSSIAN EMIGRATION IN INTERWAR POLAND: YEVGENIYA VEBER-KHIRYAKOVA

The paper described Yevgeniya Veber-Khiryakova's views on Russian emigration based on her cooperation with the Warsaw newspaper "Za Svobodu!". The context for the analysis became statements of other representatives of the Russian Diaspora in Warsaw and Paris. The analysis of journalistic writing and literary criticism have been performed, which led to the conclusion that she perceived emigration as a mission, with a special role attributed to literature. Veber-Khiryakova referred to the great traditions of Russian literature, which tried to combine aesthetic and ethical ideals, and to the idea of a writer - prophet. The texts of Veber-Khiryakova, which are part of the program of the newspaper "Za Svobodu!", testify to her affiliation with radical diaspora circles, unfavorable to any compromises with Soviet Russia.

Keywords: Yevgeniya Veber-Khiryakova, Russian emigration, interwar Poland, newspaper "Za Svobodu!", mission

Spuścizna literacka rosyjskiej emigracji w Polsce międzywojennej, reprezentowanej przez takie postacie jak: Dmitrij Fiłosofow, Michaił Arcybaszew, Aleksandr Amfitieatrow, Boris Sawinkow, Lew Gomolicki, Sołomon Bart, Władimir Brand czy też Aleksandr Chiriakow, nie doczekała się dotąd syntetycznego ujęcia oraz szeroko zakrojonych studiów obejmujących różne dziedziny, choć od lat 90. XX wieku, kiedy zainicjowano w naszym kraju badania nad diasporą, znacznie wzrosło zainteresowanie tą problematyką. Jego wyrazem są kolejne publikacje prezentujące sylwetki oraz dorobek wybranych twórców. 
Szczególne zasługi w rozwoju tych badań położył Piotr Mitzner, autor artykułów oraz dwóch monografii poświęconych Dmitrijowi Fiłosofowowi - przywódcy intelektualnemu emigracji rosyjskiej w II Rzeczpospolitej $^{1}$, a także współautor studium na temat Lwa Gomolickiego ${ }^{2}$. Nadal jednak istotne obszary dotyczące diaspory - choćby takie jak prasa - nie zostały opisane w sposób wyczerpujący. Na marginesie dociekań literaturoznawców pozostają także losy i dorobek niektórych postaci dziś zapomnianych, niegdyś zaś odgrywających znaczącą rolę w życiu kulturalnym emigracji.

Jedną z nich jest Eugenia Weber-Chiriakowa - pisarka, publicystka, krytyk literacki i tłumaczka, której działalność i poglądy staną się przedmiotem refleksji w niniejszym artykule. W centrum uwagi znajdzie się jej współpraca z ukazującym się w Warszawie dziennikiem „За Свободу!”, a przede wszystkim - opinie Weber-Chiriakowej o rosyjskiej emigracji. Interesuje nas, jak definiowała ona zadania stojące przed diasporą oraz jakie miejsce wyznaczała kulturze i literaturze. Kontekstem dla rozważań staną się wypowiedzi innych przedstawicieli emigracji, zarówno warszawskiej, jak i paryskiej.

Informacje o Weber-Chiriakowej są lakoniczne i rozproszone. Większość rosyjskojęzycznych not biograficznych powstała w oparciu о hasło: Евгения Вебер-Хирьякова, zaczerpnięte ze Stownika poetów rosyjskiej emigracji (Словарь поэтов Русского Зарубежья) opublikowanego pod redakcją Wadima Krejda w 1999 roku$^{3}$. Natomiast w Polsce najobszerniejsze dane na temat Chiriakowej zgroma-

1 Zob. P. Mitzner, Warszawski „Domek w Kołomnie”, Wydawnictwo Uniwersytetu Kardynała Wyszyńskiego, Warszawa 2014; tegoż, Warszawski krag Dymitra Fiłosofowa, Wydawnictwo Uniwersytetu Kardynała Wyszyńskiego, Warszawa 2015; D. Fiłosofow, Pisma wybrane, t. 1. Trudna Rosja (1902-1916), wybór i opracowanie P. Mitzner, przeł. H. Dubyk, Wydawnictwo Uniwersytetu Kardynała Wyszyńskiego, Warszawa 2015; tegoż, Pisma wybrane, t. 2. Rosjanin w Polsce (1920-1936), wybór i opracowanie P. Mitzner, przeł. H. Dybuk i in., Wydawnictwo Uniwersytetu Kardynała Wyszyńskiego, Warszawa 2015, i in. Kilkanaście lat wcześniej sylwetkę Fiłosofowa przybliżyła I. Obłąkowska-Galanciak w monografii „Gorzkie gody..... Publicystyczna i literacka działalność Dymitra Fiłosofowa na emigracji, Wydawnictwo Uniwersytetu Warmińsko-Mazurskiego, Olsztyn 2001.

2 Zob. P. Mitzner, L. Fleishman, Metamorfozy Lwa (Leona) Gomolickiego, przeł. R. Szczęsny, Wydawnictwo Uniwersytetu Kardynała Wyszyńskiego, Warszawa 2015. Także: J. Brzykcy, „Królewska duma z wielkiej niepomyślności”. Doświadczenie emigracji w poetyckiej perspektywie Lwa Gomolickiego, „Acta Polono-Ruthenica” 2016, nr XXI, s. 133-144. Autorka artykułu przytacza bibliografię polskich prac na temat poezji Gomolickiego.

3 Zob. http://www.russianresources.lt/archive/Weber/Weber_o.html (3.10.2018). 
dził Piotr Mitzner, który zrekonstruował jej życiorys m.in. w oparciu o opowieść autobiograficzną История женской жизни . Wątpliwości wzbudza nawet data urodzin pisarki (jedni wskazują na rok 1893, inni zaś na 1895). Eugenia Weber przyszła na świat w rodzinie żydowskiej, prawdopodobnie w Omsku, ale już jako dziecko kilkukrotnie zmieniała miejsce zamieszkania, co wynikało z charakteru pracy jej ojca. Przypuszczalnie studiowała literaturę w Petersburgu, a od 1919 roku przebywała w Harbinie, gdzie pięć at później wyszła za mąż za starszego od niej o ponad trzydzieści lat Aleksandra Chiriakowa (1863-1940) niegdyś bliskiego współpracownika Lwa Tołstoja, pisarza, krytyka literackiego oraz autora wspomnień 5 . Z Dalekiego Wschodu wraz z mężem wyjechała do Indii, a stamtąd do Europy. Najpierw zamieszkała w Berlinie, następnie w Paryżu, by w 1927 roku osiedlić się w Warszawie ${ }^{6}$.

Chiriakowowie zostali zaproszeni do stolicy odradzającej się Rzeczypospolitej przez Fiłosofowa, który po śmierci czołowego publicysty gazety „За Свободу!”, Michaiła Arcybaszewa, liczył na ich pomoc w redagowaniu periodyku7. Po przyjeździe do Warszawy Weber-Chiriakowa aktywnie włączyła się w życie rosyjskiej diaspory: została członkiem Związku Rosyjskich Pisarzy i Dziennikarzy w Polsce oraz Stowarzyszenia Literackiego. Nawiązała kontakt z czołowymi przedstawicielami emigracji; w latach trzydziestych prowadziła intensywną korespondencję z Zinaidą Gippius, co pośrednio świadczy o ich zażyłości ${ }^{8}$. Ponadto łączyły ją bliskie relacje z reprezentantami polskiej elity intelektualnej: była m.in. dobrą znajomą Marii i Józefa Czapskich, Juliana Tuwima oraz Stanisława Stempowskiego i Marii Dąbrowskiej, której dzienniki dostarczają ciekawych informacji na jej temat. Pierwsze spotkanie z rosyjską pisarką, która niemal natychmiast obdarzyła ją uwielbieniem, Dąbrowska zrelacjonowała tak:

4 Zob. P. Mitzner, Udręczona dusza Jessiki (o Jewgenii Weber-Hiriakowej), w: tegoż, Warszawski krąg Dymitra Fiłosofowa, s. 121-136. Utwór История женской жизни opublikowała gazeta „За Свободу!” w 1929 r. (w nr 222, 223, 225, 227, 229, 244, 246).

5 Więcej o nim zob. Ю. Рыкунина, Глазами „толстовца”. А.М. Хирьяков и его воспоминания, „Toronto Slavic Quarterly” 2011, no. 37, s. 243-268, http://sites. utoronto.ca/tsq/37/tsq37_rykunina.pdf.

6 Publicystka mieszkała m.in. przy ul. Konduktorskiej 14 m.12, a po rozstaniu z mężem w połowie lat 30. - przy ul. Słonecznej 50 m.15.

$7 \mathrm{~W}$ odrodzeniu gazety miała pomóc zwłaszcza literacka reputacja Chiriakowa oraz sława, jaką przyniosła mu zażyłość z Tołstojem.

$8 \mathrm{~W}$ drugiej połowie lat 30. Weber-Chiriakowa w korespondencji z Gippius informowała ją o stanie zdrowia schorowanego Fiłosofowa oraz o rosyjskiej emigracji w Polsce. 
W czasie tego wieczoru poznałam panią Eugienię Weber-Chiriakow, którą przedstawił mi Dymitr Fiłosofow. Była to maleńka trzydziestokilkoletnia pani, z namiętna twarza, w której było coś z egipskiego ptaka, nieładna, ale z urokiem i o wielkich niebieskich oczach. Przyjechała właśnie wtedy z Paryża z córeczką i mężem, o jakieś trzydzieści lat od niej starszym, niegdyś sekretarzem Lwa Tołstoja. Była to Rosjanka niezwykle inteligentna, egzaltowana, z pesymistycznym poglądem na życie, ale z wielką zdolnością do entuzjazmu. Powzięła do mnie i do St. Stemp.[owskiego] taką sympatię, że nas prawie kochała i była potem u nas częstym gościem ${ }^{9}$.

Na egzaltację czy też hiperwrażliwość publicystki jako konstytutywną cechę jej osobowości zwraca uwagę w subiektywnym, emocjonalnym liście do Gippius z 8 stycznia 1932 roku Fiłosofow:

To nieszczęsne, chore (zwłaszcza psychicznie!) stworzenie cierpi z jednej strony z powodu niebywałej „egzaltacji” [...], a z drugiej - histerii. [...] jest jak bateria elektryczna. Dotkniesz jej - lecą iskry. Albo „zachwyty”, albo „wyjątkowe" cierpienia, których nikt nie rozumie.

Z połączenia niezgody na świat i całkowitej zgody na płeć wynika jakiś psychologiczny masochizm. Zawsze „cierpi”, zawsze w „udręce”. Jeśli jej brak - wymyśla ją sobie ${ }^{10}$.

Weber-Chiriakowa zamieszczała artykuły w najważniejszych periodykach emigracyjnych w Polsce: w latach 1927-1932 w gazecie „За Свободу!”, w okresie 1932-1934 była członkiem redakcji gazety „Молва”, а od 1934 roku - tygodnika „Меч”, na którego czele stał Fiłosofow, gdzie kierowała działem „Rosja sowiecka”. Teksty podpisywała zazwyczaj panieńskim nazwiskiem E. Вeбep lub męskimi pseudonimami: Андрей Луганов, А. Палицын, В. Евгеньев; posługiwała się również inicjałami: Je. W. (E. B.) i W. Je. (B. E.).

Publicystka, doskonale władająca językiem polskim, nawiązała współpracę także z miesięcznikiem literackim i kulturalnym „Droga”, kwartalnikiem „Marchołt”, tygodnikiem społeczno-literackim „Pion”, miesięcznikiem „Przegląd Współczesny” oraz katolickim kwartalnikiem kulturalno-religijnym „Verbum”" . Recenzowała oraz tłumaczyła nowości prozy polskiej, zwłaszcza pisarek: Dąbrowskiej, Heleny

9 M. Dąbrowska, Dzienniki 1914-1965, t. III, Polska Akademia Nauk, Wydział I Nauk Społecznych, Komitet Nauk o Literaturze, Warszawa 2009, s. 130.

${ }^{10}$ D. Fiłosofow do Z. Gippius. Cyt. za: P. Mitzner, Udręczona dusza Jessiki..., s. 131-132.

${ }^{11}$ Jako „ciekawego człowieka” i „poetkę” związaną z kręiem „Verbum” oraz Zakładem dla Niewidomych w Laskach wspominał ją po latach Jerzy Giedroyc. Zob. tegoż, Autobiografia na cztery ręce, oprac. i posłowie K. Pomian, Czytelnik, Warszawa 1994, s. 15-16. 
Boguszewskiej i Poli Gojawiczyńskiej. O wrażliwości i przenikliwości Weber-Chiriakowej określających jej wysokie kompetencje jako krytyka wypowiedziała się Dąbrowska. W dzienniku 1 stycznia 1932 roku stwierdziła, że w odróżnieniu od polskich recenzentów jako jedyna potrafiła ona trafnie odczytać powieść Noce $i$ dnie: „St.[anisław] przeczytał mi bardzo piękny artykuł Chiriakowej o Nocach $i$ dniach. Nic podobnego nie mogę się od nikogo z polskich krytyków spodziewać, niestety, niestety. Pochwał w nich nie braknie, ale trafnego odczucia i zrozumienia - owszem"12.

W połowie lat 30. wraz z Fiłosofowem i Gomolickim Weber-Chiriakowa zasiadała w zarządzie rosyjsko-polskiego klubu dyskusyjnego „Domek w Kołomnie” (1934-1938), który - tu znowu odwołajmy się do opinii Dąbrowskiej - uchodził za „jedyne miejsce w Warszawie, gdzie panował [...] dobry smak"13. Prawdopodobnie na początku października 1939 roku po kapitulacji stolicy i wkroczeniu do niej hitlerowców, pisarka, która miała żydowskie korzenie, popełniła samobójstwo, przyjmując dużą dawkę środków nasennych.

Weber-Chiriakowa została współpracownicą gazety „За Свободу!” latem 1927 roku. Początkowo swe teksty przesyłała z Paryża rzadko i nieregularnie; były to głównie recenzje, przeglądy zawartości czasopism oraz opowiadania. Po przyjeździe do Warszawy zaczęła systematycznie (codziennie lub co kilka bądź kilkanaście dni) publikować na łamach gazety artykuly prezentujące jej antybolszewicką postawę. Zamieszczała własne utwory prozatorskie oraz recenzje nowości wydawniczych w „Dodatku Literackim”, przypominała tam sylwetki klasyków literatury rosyjskiej, a także komentowała prasę sowiecką i emigracyjną. Wyróżniała się pracowitością i pasją dziennikarską: niekiedy pod różnymi pseudonimami publikowała kilka tekstów w tym samym numerze gazety. Często analizowała sytuację w ZSRR oraz omawiała najważniejsze problemy emigracji, dając się poznać jako publicystka bezkompromisowa wobec bolszewików, uważna obserwatorka życia społeczno-politycznego i kulturalnego oraz przenikliwa czytelniczka utworów literackich.

Niemal od pierwszych dni po przyjeździe do Polski Weber-Chiriakowa włączyła się do prowadzonej na łamach gazety „За Свободу!” polemiki dotyczącej kondycji emigracji oraz stojących przed nią zadań, ściślej - jej miejsca i roli w odrodzeniu Rosji. Analogicznie do

${ }^{12}$ M. Dąbrowska, Dzienniki 1914-1965, t. II, Polska Akademia Nauk, Wydział I Nauk Społecznych, Komitet Nauk o Literaturze, Warszawa 2009, s. 141.

${ }^{13}$ Tamże, s. 222. 
znacznej części rosyjskiej diaspory, zwłaszcza starszego pokolenia, Weber-Chiriakowa postrzegała emigrację jako misję. „Inna Rosja” miała być strażniczką narodowej tożsamości, negowanej i niszczonej przez bolszewików tradycji kulturowej i społecznej, spadkobierczynią pamięci i wartości duchowych, które winny sprzyjać przyszłemu odrodzeniu ojczyzny. Wyjątkowe znaczenie w kształtowaniu samoświadomości oraz światopoglądu rosyjskiego inteligenta miała w oczach uchodźców kultura, przede wszystkim zaś - literatura. Dobitnie cele te sformułował Iwan Bunin w paryskim wystąpieniu Миссия русской эмиграции z 16 lutego 1924 roku, gdzie uznał emigrantów za obrońców wiecznych, boskich fundamentów ludzkiego bytu ${ }^{14}$. Także Dmitrij Mereżkowski, apelując w 1927 roku o jedność duchową diaspory, wskazywał na ciężar spoczywającej na niej odpowiedzialności za losy świata: „Тяжела и грозна павшая на нас ответственность: мы ведь сейчас, может быть, отвечаем не только за Россию, но и за мир,

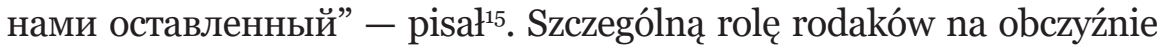
jako depozytariuszy prawdy i wartości podkreślała również Gippius, przede wszystkim w swej publicystyce i Dziennikach petersburskich, gdzie dawała świadectwo zbrodniczemu charakterowi sowieckiego imperializmu.

Do aktywności w budzeniu sumień rodaków nawoływał emigracyjnych literatów w dzienniku „За Свободу!” osiadły w 1920 roku w Warszawie Fiłosofow, którego rozległa działalność kulturalna i społeczno-polityczna kształtowała oblicze rosyjskiej diaspory w Polsce międzywojennej. Jako redaktor opiniotwórczej gazety Fiłosofow propagował wśród jej czytelników przeświadczenie o ich szczególnym obowiązku moralnym wobec Rosji oraz misji - politycznej i kulturalnej; pytał o tożsamość i zadania stojące przed emigracją oraz o drogi jej rozwoju, poszukiwał też dla niej pozytywnego programu ${ }^{16}$. W artykuleДолг русских писателей эмигрантов оdpowiedzialność za ojczyznę uznał za obowiązek, od którego nie powinni uchylać się zwłaszcza literaci:

Именно сейчас, когда эмигрантское «патриотичество» занимается желанием резины, когда эмигрантская молодежь все больше и больше

${ }^{14}$ Zob. И.А. Бунин, Миссия русской эмиграции, w: tegoż, Публицистика 19181953 годов, ред. О.Н. Михайлов, Наследие, Москва 1998, s. 148.

15 Д. С. Мережковский, О свободе и России, „Новый корабль” 1927, nr 1, s. 22.

${ }^{16}$ Szerzej na ten temat zob. I. Krycka-Michnowska, Dymitr Fiłosofow o Adamie Mickiewiczu i literaturze polskiej, w: L. Paučová, I. Pospišil, M. Zelenka (red.), Klićové problemy soućasné slavistiky. Kolektivni monografie, Sojnek, Brno 2017, s. 93-101. 


\section{Z DZIEJÓW ROSYJSKIEJ EMIGRACJI...}

устраняется от политики голос писателей должен звучать особенно сильно.

Но, увы! Писатели «устали», разочаровались и замолкли.

И это великая беда ${ }^{17}$.

Linię programową gazety „За Свободу!” wyznaczała dewiza „Za Ojczyznę i Wolność”. Na jej łamach od chwili powstania nawoływano do aktywnej walki z reżimem bolszewickim w imię odrodzenia Rosji, a w drugiej połowie lat dwudziestych jej redakcja nawiązała współpracę z radykalnym paryskim tygodnikiem Władimira Burcewa i Siergieja Mielgunowa „Борьба за Россию”. Poglądy polityczne Weber-Chiriakowej, która należała do najbliższych współpracowników gazety, odzwierciedlają jej program.

Postawę ideową publicystki wyraża napisana jeszcze w Paryżu recenzja drugiego tomu zbioru artykułów Arcybaszewa Черемуха (записки писателя) z 26 czerwca 1927 roku. Książkę pisarza, który w artykule Жгучий вопрос wyznał, że opuścił Rosję sowiecką nie z obawy przed śmiercią i głodem, lecz by nie stać się niewolnikiem ${ }^{18}$, postrzega recenzentka jako wyraz niezachwianego, głębokiego patriotyzmu autora oraz jego nieprzejednania i nienawiści do bolszewików. Weber-Chiriakowa utożsamia się z propagowaną w tym tomie postawą obywatelską, akcentując patos oraz moc przekazu płynące z jego kart. Wyraża opinię, że Arcybaszew, który „stracił wszystko poza świętą nienawiścią" do katów Rosji, poruszał tematykę najistotniejszą dla emigrantów, konieczną dla zachowania miłości do ojczyzny oraz wiary w jej odrodzenie. Odtąd uznaje tego skandalizującego niegdyś beletrystę za obrońcę prawdy i wolności oraz proroka, który zgodnie z Puszkinowskim przesłaniem „przepala słowem serca ludzi”:

Автор Смерти Ланде, У последней черты, Диких, писатель талантливый и своеобразный, он не был для нашего поколения ни учителем, ни руководителем, ни пророком. И вот теперь открылся новый Арцыбашев, новый писатель, новый человек властно тронул душу ${ }^{19}$.

Podobnie ocenił Arcybaszewa Marian Zdziechowski, który w szkicu z 1927 roku podkreślił jego wyjątkową rolę dla duchowości diaspory, zwłaszcza w ostatnim okresie życia:

${ }_{17}$ Д. Философов, Долг русских писателей эмигрантов, „За Свободу!”, 17.07.1929.

${ }_{18}$ Zob. М. П. Арцыбашев, Записки писателя. Дьявол. Современники о М.П. Арцыбашеве, red. Т.Ф. Прокопов, Интелвак, Москва 2006, s. 361.

19 А. Луганов, Единое, „За Свободу!”, 26.06.1927. 
Michał Arcybaszew był więcej, niż znakomitym powieściopisarzem. W ostatnich latach życia swojego, spędzonych w Warszawie, był dla narodu swojego prorokiem. Jak prorocy Izraela na wygnaniu, [...] budził on sumienia, krzepił serca, wzywał do nieubłaganej, a świętej walki, przekleństwem piętnował leniwych i małodusznych. Potęgą słowa nie dorównywał mu nikt ${ }^{20}$.

Gorzką opinię na temat statusu i kondycji literatury oraz prasy emigracyjnej wydaje Weber-Chiriakowa w artykule Смена идеалов (1928), gdzie odnotowuje diametralną zmianę, która zaszła w kulturze europejskiej i rosyjskiej w ciągu dziesięciolecia od przewrotu bolszewickiego. Analogicznie do Fiłosofowa jawi się także jako rzeczniczka wartości w literaturze, jej szczególnego znaczenia w zachowaniu rosyjskości diaspory oraz etosu pisarza:

за последнее десятилетие так неузнаваемо преобразился культурный мир, что до сих пор трудно не только понять его новый облик, но и просто привыкнуть к нему [...]. Когда-то, и совсем недавно в сущности, умственные и духовные стремления вызывали уважительное благоговение. Личный героизм, подвиги человеколюбия, самоотречение заставляли преклоняться перед олицетворяющими их людьми. Художественные произведения заставляли гореть и биться человеческие сердца. Об этом говорило искусство, об этом говорила литература. И служебные проводники культурной жизни - газеты писали о том, что было дорого и нужно читающим. [...]

Когда-то литература учила жить, [...] печать стремилась руководить в духовном и умственном отношении. И учились, и руководству следовали ${ }^{21}$.

Za główny problem kultury uważa jej odchodzenie od misyjnego charakteru, deficyt posłannictwa, komercjalizację i merkantylizację: literatura, która niegdyś niosła wyraźny przekaz moralny oraz ideowy („uczyła życia”), jej zdaniem niemal całkowicie wyzbyła się ideałów. Pisarka z niepokojem dostrzega rosnącą interesowność literatów oraz redaktorów gazet i czasopism, które zamiast pełnić funkcję wychowawczą, rozwijać świadomość oraz kształtować upodobania czytelników starają się dogodzić niewybrednym gustom tłumu ${ }^{22}$.

Weber-Chiriakowa wypowiada się nie tylko w kwestiach sztuki, występuje również jako moralistka. Zauważa szerzący się na szeroką skalę hedonizm oraz kult złotego cielca, ostrzega przed płycizną i jednostronnością rozwoju współczesnego człowieka oraz społeczeństwa.

${ }^{20}$ M. Zdziechowski, Arcybaszew i kwestia rosyjska w Polsce, w: tegoż, Od Petersburga do Leningrada, [s.n.], Wilno 1934, s. 30.

${ }^{21}$ А. Луганов, Смена идеалов, „За Свободу!”, 5.10.1928.

${ }^{22}$ Tamże. 
Piętnuje duchowe ubóstwo tych, których interesują przede wszystkim „ciało i pieniądze”; surowo ocenia sytuację, gdy dobra materialne stają się bożkiem, któremu za wszelką cenę i wszelkimi możliwymi środkami należy służyć. Choć jest krytyczna wobec zachodzących procesów, odnotowuje także pozytywne zjawiska w kulturze. Z uznaniem wypowiada się o autorach, którzy w trudnych emigracyjnych warunkach i czasach „triumfującej banalności” pielęgnują tradycje przedrewolucyjnej literatury i prasy, nie poddając się pokusie dogodzenia gustom nowego czytelnika. Pisząc o nich, używa nacechowanych dodatnio epitetów „wspaniały” oraz „prawdziwy” („wspaniałe książki prawdziwych pisarzy”) ${ }^{23}$.

Publicystka domaga się od literatów syntezy ideałów etycznych i estetycznych, bo - jak przypomina - „książka jest czymś więcej niż tylko pokrytym znakami graficznymi” zbiorem kartek. Kładzie nacisk na przekaz, który z niej płynie, wymowę ideową oraz cele, które przyświecają pisarzowi. Autorów, których twórczość wypływa z głębi serca, i którzy poruszają serca innych, porównuje do biblijnych żniwiarzy, wskazując tym samym na ich posłannictwo oraz szczególną odpowiedzialność nie tylko przed ludźmi, ale i przed Bogiem ${ }^{24}$.

Jako przeciwwagę wobec sytuacji twórców emigracyjnych przywołuje Weber-Chiriakowa sytuację pisarzy w ZSRR, obnażając przy tej okazji paradoksy sowieckiej rzeczywistości ${ }^{25}$. Zwraca uwagę na ostrą cenzurę partyjną i rządową, inwigilację i kontrolę sztuki, a w efekcie - brak wolności słowa. Już w 1933 roku wyraża opinię, że status literatury znacznie pogorszył się od czasu powołania do życia Związku Pisarzy Radzieckich. Publicystka, która stawia literaturze i jej twórcom wysokie wymagania, nie stroni od ostrych, kategorycznych sądów. Wskazuje zwłaszcza na drastyczne obniżenie się jakości sztuki, która zamiast nieść wartości uniwersalne, zaczęła służyć państwu i partii, realizując tzw. zamówienie społeczne. Jej zdaniem literatura o ściśle utylitarnym charakterze, ograniczająca się do produkcji utworów okolicznościowych, przestała być sztuką, zaś sowieccy pisarze przeobrazili się w zniewolonych duchowo urzędników do zadań specjalnych partii. Jako przykład literatów zniewolonych, poni-

\footnotetext{
${ }^{23}$ Tamże

${ }^{24}$ Zob. А. Луганов, Побег зеленый, „За Свободу!”, 3.01.1931. Wysoko ceniła pisarka m.in. twórczość poetów młodego pokolenia grupy „Перекресток” (Jurija Mandelsztama, Dowida Knuta, Jurija Terapiano i in.). Tamże.

${ }^{25}$ Е. Вебер, Советские писатели о себе, „Молва”, 29.10.1933.
} 
żonych i upodlonych podaje Fiodora Gładkowa, Mariettę Szaginian i Wierę Inber ${ }^{26}$.

Lejtmotywem warszawskich artykułów Weber-Chiriakowej jest moralna odpowiedzialność emigracji za zachowanie dziedzictwa kulturowego Rosji, jej odrodzenie i przyszłość. Pretekstem do refleksji nad kondycją diaspory staje się dla publicystki książka Nikołaja Goldenweisera-Lubimowa Да здравствует эмиграция! (1929). Głównym problemem, jaki sygnalizuje recenzentka, jest wyradzanie się diaspory: śmierć przedstawicieli starszej generacji, rozpad więzi między młodszymi oraz wynaradawianie się dzieci Rosjan; jej niepokój budzi także brak autentycznego przywództwa politycznego emigracji. Toteż Weber-Chiriakowa stara się zdefiniować stojące przed nią zadania:

У русской эмиграции есть своя [...] задача [...] Задача неотложная, малозаметная, непрерывная и настойчивая.

Долг русской эмиграции перед Россией сберечь для нее культурные русские силы, воспитать русских людей, создать духовную армию, сильную своей верой в Россию, своей готовностью жертвенно служить ей.

Если эмиграция осуществит эту задачу, соберет, а не растратит духовные русские силы, воспитает русских людей, - ее существование будет оправдано перед ее собственной совестью ${ }^{27}$.

Do jej najważniejszych obowiązków zalicza konsolidację sił duchowych w walce z bolszewikami, których uznaje za wrogów Rosji i ludzkości, oraz skupienie się na wychowaniu świadomych pokoleń nowych Rosjan, kochających ojczyznę i gotowych ofiarnie jej służyć. Publicystka podejmuje podobną tematykę także w tekście pod wymownym tytułem Живые и мертвые, gdzie przedstawicieli diaspory dzieli na ludzi świadomych własnego dziedzictwa kulturowego oraz moralnych zobowiązań wobec samych siebie i ojczyzny („żywych”), oraz duchowo martwych ${ }^{28}$.

Oprócz artykułów analitycznych, poświęconych wybranym problemom diaspory rosyjskiej, pisarka zamieszczała w warszawskiej gazecie także teksty o charakterze syntetyzującym. Starała się spojrzeć krytycznie na jej przeszłość oraz wyznaczyć perspektywy jej dalszego rozwoju, o czym świadczy tekst Эмиграция на переломе z 1929 roku. Weber-Chiriakowa sądzi, że w końcu lat 20. emigracja znalazła się w punkcie zwrotnym swej historii. Mimo negatywnych uwag pod jej adresem mniema, że jest to zwrot w dobrym kierunku, co zapowia-

${ }^{26}$ Tamże.

${ }_{27}$ А. Луганов, Эмиграчия, „За Свободу!”, 25.04.1929.

${ }^{28}$ Zob. А. Луганов, Живые и мертвые, „За Свободу!”, 1.06.1929. 
da projekt „praktycznego zjednoczenia diaspory” i jej transformacji „ze społeczno-ekonomicznego chaosu” w „społeczno-ekonomiczny organizm”. Temu celowi ma służyć wspierana przez nią idea utworzenia ponadpartyjnej organizacji, niosącej materialną oraz duchową pomoc rosyjskim emigrantom, a zwłaszcza ich dzieciom i młodzieży, której działalność pozwoli kolejnym pokoleniom zachować więź z ojczystym krajem i tradycją ${ }^{29}$.

$\mathrm{Na}$ łamach periodyku pisarka podejmuje także polemikę z diasporą paryską. Publiczną i prywatną dyskusję na temat misji emigracji oraz jej odpowiedzialności przed współczesnymi i potomnymi prowadził z osiadłymi w Paryżu Mereżkowskimi Fiłosofow. Starał się dowieść byłym przyjaciołom, że prowadzone przez rosyjskich emigrantów politycznych w Warszawie działania o charakterze antybolszewickim uprawniają to miasto do miana stolicy rosyjskiej emi-

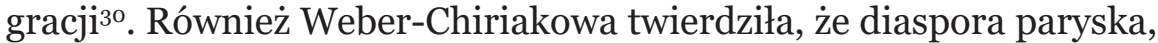
która w pierwszych latach po rewolucji stanowiła polityczną i kulturalną awangardę, w latach 30. znalazła się w defensywie. Charakteryzując ją, w artykule Болезни эмигрантского „тыла” posługuje się retoryką wojenną. Zdaniem autorki cechuje ją „psychologia tyłów” z symptomatyczną dla niej pasywnością, schyłkowością, moralnym defetyzmem i tendencjami restauracyjnymi. Diaspora w Paryżu, jak mniema, odeszła od prawdziwych zadań, te zaś przejęły ośrodki prowincjonalne, stając się jej forpocztą ${ }^{31}$.

Publicystka nieustannie przypomina o konieczności walki o wolną Rosję oraz zainteresowania jej losem społeczności międzynarodowej (zwłaszcza Ligi Narodów). Wzywa diasporę do jednoznacznego opowiedzenia się przeciwko bolszewikom i ostro krytykuje tych, którzy szukają jakiegokolwiek kompromisu z sowietami ${ }^{32}$. Ostrzega także przed konsekwencjami braku zaangażowania:

Добиться того, чтобы судьбой России ответственно заинтересовался оплот международной жизни - наш долг.

И время не терпит.

Грозный час, который давно пробил для России, наступает для всего мира ${ }^{33}$.

${ }^{29}$ А. Луганов, Эмиграция на переломе, „За Свободу!”, 1.06.1929.

$3^{30}$ Zob. O.P. Демидова, Между столицей ипровинцией (из архиваД. Философова), w: Культура русской диаспоры. Эмиграция и мемуары. Сборник статей, отв. ред. С. Доценко, Таллин 2009, s. 51.

${ }^{31}$ А. Палицын, Болезни эмигрантского „тыла”, „За Свободу!”, 19.04.1931.

${ }^{22}$ Zob. А. Палицын, Гнилая почва, „За Свободу!”, 13.02.1932.

33 Tegoż, Грозный час, „За Свободу!”, 17.06.1931. 
Upływ lat nie wpływa na złagodzenie postawy i poglądów publicystki. Weber-Chiriakowa konsekwentnie stara się rozbudzać w emigrantach świadomość obywatelskiego obowiązku, burzyć ich spokój i samozadowolenie. Nawołuje do konsolidacji sił i wspólnego działania w imię odrodzenia ojczyzny. Sądzi, że bierność jest moralnie niedopuszczalna:

Борьба обязательна. Всеми мерами, всеми способами. И первоусловие борьбы $-[. .$.$] сознание ее необходимости, своего личного в ней участия,$ своей за ее исход ответственности. [...].

Она должна понять и необходимость «упражнения» своих общественных способностей, внимательным изучением совершающегося в мире, должна понять необходимость гражданского воспитания своего заново, должна отказаться от покоя, поняв и признав свою ответственность за судьбы России ${ }^{34}$.

Niebezpieczne dla kondycji diaspory symptomy, świadczące o jej duchowym kryzysie, odnotowuje Weber-Chiriakowa w artykule Bo дни сомнений (Ответственность эмиграции), jednym z ostatnich, jakie zostały opublikowane na łamach gazety przed jej zamknięciem 3 kwietnia 1932 roku. Publicystka zwraca uwagę na powolną degenerację, pasywność oraz panujące $\mathrm{w}$ szeregach emigracji pesymizm, zniechęcenie i zmęczenie, które - jak sądzi - mogą przyczynić się do groźnego w skutkach zwycięstwa moralnego bolszewików; toteż z patosem apeluje o aktywną postawę:

Для эмиграции вне борьбы нет морального спасения, нет оправдания, нет выхода. Отказавшись от этого пути, она перестает быть эмиграцией, она Россию предает, от права сынами ее быть отрекается.

Не о борьбе вооруженной, не о боевых выпадках в Россию я говорю. Это дело избранных, немногих славный путь [...]. Есть иные виды борьбы. Но основа ее одна: моральное неприятие большевизма, недопущение и тени компромиссов в отношении к отравителям самой идеи родины, «идеи» России ${ }^{35}$.

Analiza publicystyki oraz krytyki literackiej Weber-Chiriakowej dowodzi, że choć wiekowo pisarka należała do młodszego pokolenia emi-

${ }^{34}$ Е. Вебер, Во дни сомнений (Ответственность эмиграции), „За Свободу!”, 17.02.1932.

35 Е. Вебер, Во дни сомнений (Ответственность эмиграции), „За Свободу!”, 6.03.1932. Zdaniem publicystki stosunek do bolszewizmu określił głęboki podział Rosjan za granicą na „emigrantów” i „uciekinierów-filistrów”. „Prawdziwy emigrant" to - według niej - człowiek, który nie wyrzekł się idei wolnej Rosji, poczucia dumy narodowej i godności. Tamże. 
gracji, mentalnie była bliższa generacji starszej, podzielając jej poglądy o posłannictwie na wygnaniu i o szczególnej roli literatury. Publicystka odwoływała się do koncepcji pisarza - proroka, nauczyciela, moralisty oraz do tradycji klasycznej literatury rosyjskiej, która starała się łączyć ideały estetyczne z etycznymi. Wymowa tekstów Weber-Chiriakowej świadczy o jej przynależności do radykalnych kręgów diaspory, nieprzychylnych wobec jakichkolwiek kompromisów z Rosją sowiecką; używając wojskowej nomenklatury tej autorki, można byłoby je nazwać „emigracją walczącą”. W artykułach, które doskonale wpisywały się w założenia programowe dziennika „За Свободу!”, pisarka uczyła odpowiedzialności obywatelskiej, starała się budzić sumienia rodaków, poczucie obowiązku wobec ojczyzny oraz ducha aktywizmu. Sama dług moralny wobec Rosji spłacała angażując się w działalność gazety, którą uznawała za przyczółek toczącej się wojny z bolszewikami.

\section{REFERENCES}

Artsybashev, Mikhail. Zapiski pisatelya. D'yavol. Sovremenniki o M.P. Artsybasheve. (Ed.) Prokopov, Timofey. Moskva: Intelvak, 2006 [Арцыбашев, Михаил. Записки писателя. Дьявол. Современники о М.П. Арцыбашеве. (Ред.) Прокопов, Тимофей. Москва: Интелвак, 2006].

Brzykcy, Jolanta. "Królewska duma z wielkiej niepomyślności'. Doświadczenie emigracji w poetyckiej perspektywie Lwa Gomolickiego.” Acta Polono-Ruthenica 2016, no. XXI. 133-144.

Bunin, Ivan. "Missya russkoy emigratsii." Bunin, Ivan. Publitsistika 1918-1953 godov. (Ed.) Mikhaylov, Oleg. Moskva: Nasledye, 1998. 147-150 [Бунин, Иван. „Миссия русской эмиграции.” Бунин, Иван. Публицистика 1918-1953 годов. (Ред.) Михайлов, Олег Николаевич. Москва: Наследие, 1998. 147-150].

Dąbrowska, Maria. Dzienniki 1914-1965. T. II i III. Warszawa: Polska Akademia Nauk, Wydział I Nauk Społecznych, Komitet Nauk o Literaturze, 2009.

Demidova, Ol'ga. "Mezhdu stolitsey i provintsey (iz arkhiva D. Filosofova)." Kul'tura russkoy diaspory. Emigratsya i memuary. Sbornik statey. (Ed.) Dotsenko, Sergey. Tallin: Tallinnskiy universitet, 2009. 46-61 [Демидова, Ольга. "Между столицей и провинцией (из архива Д. Философова).” Культура русской диаспоры. Эмиграция и мемуары. Сборник статей. (Ред.) Доценко, Сергей. Таллин: Таллиннский университет, 2009. 46-61].

Filosofov, Dmitriy. "Dolg russkikh pisateley emigrantov." Za Svobodu! 17.07.1929 [Философов, Дмитрий. “Долг русских писателей эмигрантов.” За Свободу!, 17.07.1929].

Fiłosofow, Dymitr. Pisma wybrane. T. I. Trudna Rosja (1902-1916). Ed. Mitzner, Piotr. Transl. Dubyk, Halina. Warszawa: Wydawnictwo Uniwersytetu Kardynała Wyszyńskiego, 2015.

Fiłosofow, Dymitr. Pisma wybrane. T. II. Rosjanin w Polsce (1920-1936). Ed. Mitzner, Piotr. Transl. Dybuk, Halona et al. Warszawa: Wydawnictwo Uniwersytetu Kardynała Wyszyńskiego, 2015. 
Giedroyc, Jerzy. Autobiografia na cztery ręce. Oprac. i posłowie Pomian, Krzysztof. Warszawa: Czytelnik, 1994.

Krycka-Michnowska, Iwona. "Dymitr Fiłosofow o Adamie Mickiewiczu i literaturze polskiej.” Klićové problemy soućasné slavistiky. Kolektivni monografie. (Eds.) Paučová, Lenka. Pospišil, Ivo. Zelenka, Miloš. Brno: Sojnek, 2017. 93-101.

Luganov, Andrey. "Yedinoye." Za Svobodu!, 26.06.1937 [Луганов, Андрей. "Единое.” За Свободу! 26.06.1927].

Luganov, Andrey. "Zhyvye i mertvye.” Za Svobodu!, 1.06.1929 [Луганов, Андрей. “Живые и мертвые.” За Свободу!, 1.06.1929].

Luganov, Andrey. "Pobeg zelonyy". Za Svobodu!, 3.01.1931 [Луганов, Андрей. "Побег зеленый.” За Свободу!, 3.01.1931].

Luganov, Andrey. "Smena idealov." Za Svobbodu!, 5.10.1928 [Луганов, Андрей. Смена идеалов.” За Свободу!, 5.10.1928].

Luganov, Andrey. "Emigratsya." Za Svobodu!, 25.04.1929 [Луганов, Андрей. "Эмиграция." За Свободу!, 25.04.1929].

Luganov, Andrey. "Emigratsya na perelome." Za Svobodu!, 1.06.1929. [Луганов, Андрей. “Эмиграция на переломе.” За Свободу!, 1.06.1929].

Merezhkovskiy, Dmitriy. O svobode i Rossii." Novyy korabl' 1927, no. 1 [Мережковский, Дмитрий Сергеевич. О свободе и России.” Новый корабль 1927, no. 1].

Mitzner, Piotr. Fleishman, Lazar. Metamorfozy Lwa (Leona) Gomolickiego. Transl. Szczęsny, Robert. Warszawa: Wydawnictwo Uniwersytetu Kardynała Wyszyńskiego, 2015.

Mitzner, Piotr. Warszawski "Domek w Kołomnie". Warszawa: Wydawnictwo Uniwersytetu Kardynała Wyszyńskiego, 2014.

Obłąkowska-Galanciak, Iwona. “Gorzkie gody...”. Publicystyczna i literacka działalność Dymitra Fiłosofowa na emigracji. Warszawa: Wydawnictwo Uniwersytetu Warmińsko-Mazurskiego, 2001.

Palitsyn, A. "Bolezni emigrantskogo 'tyla". Za svobodu!, 19.04.1931 [Палицын, А. “Болезни эмигрантского 'тыла”. За Свободу!, 19.04.1931].

Palitsyn, A. "Gnilaya pochva." Za Svobodu!, 13.02.1932 [Палицын, А. "Гнилая почва.” За Свободу!, 13.02.1932].

Palitsyn, A. "Groznyy chas.” Za Svobodu!, 17.06.1931 [Палицын, А. “Грозный час.” За Свободу!, 17.06.1931].

Rykunina, Yuliya. "Glazami 'tolstovtsa.' A. M. Khiryakov i ego vospominanya.” Toronto Slavic Quarterly 2011, no. 37 [Рыкунина, Юлия. “Глазами 'толстовца'. A.М. Хирьяков и его воспоминания.” Toronto Slavic Quarterly 2011, no. 37] $<$ http://sites.utoronto.ca/tsq/37/tsq37_rykunina.pdf>.

Veber, Evgenya. "Vo dni somneniy (Otvetstvennost' emigratsii)." Za Svobodu!, 17.02.1932 [Вебер, Евгения. “Во дни сомнений (Ответственность эмиграции).” За Свободу!, 17.02.1932].

Veber, Evgenya. "Vo dni somneniy (Otvetstvennost' emigratsii)." Za Svobodu!, 6.03.1932 [Вебер, Евгения. “Во дни сомнений (Ответственность эмиграции).” За Свободу!, 6.03.1932].

Veber, Evgenya. "Sovetskiye pisatel'i o sebe.” Molva, 29.10.1933 [Вебер, Евгения. “Советские писатели о себе.” Молва, 29.10.1933].

„Veber-Khiryakova Evgenya.” Slovar’ poetov russkogo zarubezhya. (Ed.) Kreyd, Vadim [Евгения Вебер-Хирьякова. Словарь поэтов русского зарубежья. (Ред.) Крейд, Вадим] <http://www.russianresources.lt/archive/Weber/Weber_o.html>.

Zdziechowski, Marjan. Od Petersburga do Leningrada. Wilno: [s.n.], 1934. 